\title{
Populasi Penggerek Batang Padi pada Ekosistem Sawah Organik dan Sawah Anorganik
}

\author{
Mochamad $\operatorname{Hadi}^{\left.1{ }^{1 *}\right)}$, RC. Hidayat Soesilohadi ${ }^{2 * *)}$, \\ FX. Wagiman ${ }^{3)}$, Yayuk Rahayuningsih Suhardjono ${ }^{4)}$ \\ 1) Jurusan Biologi FMIPA UNDIP Semarang 50275. ${ }^{2)}$ Fakultas Biologi UGM. ${ }^{3)}$ Fakultas Pertanian UGM. ${ }^{4)}$ Bagian \\ Zoologi, Litbang Biologi LIPI \\ *) Telp 024 6704226; 08122834226; Fax 02476480923 e-mail hadi_tamid@yahoo.co.id \\ ${ }^{2)}$ hid_soesi@yahoo.com
}

\begin{abstract}
Rice stem borer (RSB ) is a major pest for rice in Central Java in the past ten years as well as previous years . The presence of RSB occurs during the rice growing season with a high intensity, especially in the rainy season . RSB which is the main type, yellow RSB Scirpophaga incertulas Walker and white S. innonata. Walker. Other types are pink Sesamia inferens Walker, striped Chilo suppressalis Walker, headed black C. polychrysus Meyrick, and shiny $C$. auricilius Dudgeon. Organic farming in Central Java is still not widely applied so it is still very less information available, including information on the fluctuations in species diversity and population abundance of RSB. In this study examined the types and abundance fluctuations keenekaragaman RSB populations in rice field ecosystem organic and inorganic. Research will be conducted for one year (3 times transplanting rice) paddy ecosystems in organic and inorganic Bakalrejo Village, District Susukan, Semarang regency. The results showed that the dominant RSB is yellow S. incertulas. Yellow RSB found in every season paddy rice planting in both organic and inorganic rice. While the pink, shiny and white RSB, occasionally encountered. The RSB encountered seem to prefer the ecosystem tend rice paddy organic than inorganic .
\end{abstract}

Keywords : rice stem borer ( RSB ), organic rice ecosystem, inorganic rice ecosystem.

\begin{abstract}
Abstrak
Penggerek batang padi (PBP) merupakan organisme pengganggu tanaman utama bagi tanaman padi di Jawa Tengah dalam sepuluh tahun terakhir. Kehadiran PBP terjadi selama musim tanam padi dengan intensitas yang tinggi terutama pada musim penghujan. Jenis PBP yang utama adalah PBP kuning Scirpophaga incertulas Walker, dan putih S. innonata Walker. Jenis yang lain adalah PBP merah jambu Sesamia inferens Walker, bergaris Chilo suppressalis Walker, berkepala hitam C. polychrysus Meyrick, dan berkilat C. auricilius Dudgeon. Pertanian organik di Jawa Tengah masih belum banyak diterapkan sehingga masih sangat kurang informasi yang tersedia, termasuk informasi mengenai fluktuasi keanekaragaman jenis dan kelimpahan populasi PBP. Pada penelitian ini diteliti mengenai fluktuasi keanekaragaman jenis dan kelimpahan populasi PBP di ekosistem sawah organik dan anorganik. Penelitian dilakukan selama satu tahun (3 kali tanam padi) di ekosistem sawah organik dan anorganik Dusun Dolok, Desa Bakalrejo, Kecamatan Susukan, Kabupaten Semarang. Hasil penelitian menunjukkan PBP yang dominan adalah PBP kuning $S$. incertulas. PBP kuning dijumpai pada setiap musim tanam padi baik di sawah organik maupun sawah anorganik. Sedangkan PBP merah jambu, PBP putih dan PBP berkilat, dijumpai kadangkadang saja. PBP yang dijumpai cendrung lebih memilih ekosistem sawah organik dibandingkan sawah anorganik.
\end{abstract}

Kata kunci : penggerek batang padi (PBP),ekosistem sawah organik, ekosistem sawah anorganik

\section{PENDAHULUAN}

Shcircphophaga incertulas (PBP Kuning) merupakan salah satu organisme pengganggu tanaman padi yang sangat merugikan di Indonesia dan beberapa negara di Asia. Kemunculan serangan penggerek batang padi kuning selalu dilaporkan hampir di seluruh daerah di Indonesia dan beberapa daerah bahkan menunjukkan kecenderungan yang 
meningkat dari waktu ke waktu (Kalshoven, 1981; Hatori \& Siwi, 1986; Urip, 2009).

Penggerek batang padi terdapat sepanjang tahun dan menyebar di seluruh Indonesia pada ekosistem padi yang beragam. Intensitas serangan penggerek batang padi pada tahun 1998 mencapai $20,5 \%$ dengan luas daerah yang terserang mencapai 151.577 ha. Kehilangan hasil akibat serangan PBP pada stadia vegetatif memang tidak besar karena tanaman masih dapat mengkonpensasi dengan membentuk anakan baru (sampai dengan 30\%). Gejala serangan pada stadia generatif menyebabkan malai yang muncul berwarna putih dan hampa (tidak berisi) (Balai Besar Penelitian Tanaman Padi, 2009).

Ada enam jenis penggerek batang padi (PBP) yang menyerang tanaman padi di Indonesia, lima jenis dari famili Pyralidae, yaitu Scirpophaga incertulas Walker (PBP kuning), Scirpophaga innotata Walker (PBP putih), Chilo suppressalis Walker (PBP bergaris), Chilo auricilius Dudgeon (PBP berkilat), Chilo polychrysus Meyrick (PBP berkepala hitam) dan satu jenis dari famili Noctuidae, yaitu Sesamia inferens Walker (PBP merah jambu). Namun demikian dari enam jenis PBP yang terdapat di Indonesia, hanya empat jenis yang sering menyerang tanaman padi, yaitu $S$. incertulas, S. innotata, Chilo suppressalis, dan $S$. inferens. Dan dari empat jenis tersebut, penggerek batang padi kuning $S$. incertulas adalah yang paling dominan dan paling luas persebarannya di Indonesia (Siwi, 1979; Soehardjan, 1983; Soejitno, 1986; Sutarna, 1999).

Pada tahun 2005 - 2009 dari 35 kabupaten/kota di Jawa Tengah, semuanya terjadi serangan PBP dengan intensitas serangan yang bervariasi, yaitu intensitas serangan ringan, sedang, berat dan puso. Intensitas serangan yang ringan terjadi di semua (35) wilayah kabupaten/kota. Intensitas serangan sedang terjadi di 28 wilayah kabupaten/kota. Intensitas serangan berat terjadi di 16 wilayah kabupaten/kota. Sedangkan intensitas serangan sangat berat atau puso terjadi di 11 wilayah kabupaten/kota (BPTPH Jateng, 2005-2009) . Intensitas serangan secara kualitatif dinyatakan dalam kategori serangan ringan (0-25\%), sedang (25-50\%), berat (50-90\%) dan puso (>90\%). (Direktorat Perlindungan Tanaman Pangan
Direktorat Jenderal Tanaman Pangan Departemen Pertanian, 2008).

Intensitas serangan penggerek batang padi akan tinggi pada saat musim penghujan ketika populasi tanaman padi juga melimpah dan kelembaban udara sangat tinggi. Di Jawa Tengah seperti juga di daerah lain jenis penggerek batang padi kuning diikuti penggerek batang padi putih merupakan jenis yang dominan dibanding jenis penggerek batang lain.

Pertanian organik adalah sistem manajemen produksi terpadu yang menghindari penggunaan pupuk buatan, pestisida kimia dan hasil rekayasa genetik, menekan pencemaran udara, tanah, dan air. Pertanian organik dinilai lebih menguntungkan karena nilai jual produknya lebih tinggi dibandingkan produk pertanian anorganik. Keuntungan yang diperoleh dari pertanian organik lebih tinggi $15-20 \%$ dibanding pertanian an organik (Mutiarawati, 2006; Sutanto, 2002; Kunia, 2011).

Sistem pertanian organik sangat memperhatikan kondisi lingkungan dengan mengembangkan metode budidaya dan pengolahan berwawasan lingkungan yang berkelanjutan. Sistem pertanian organik diterapkan berdasarkan atas interaksi tanah, tanaman, hewan, manusia, mikroorganisme, ekosistem dan lingkungan dengan memperhatikan keseimbangan dan keragaman hayati (Mutiarawati, 2006; Sutanto, 2002).

Dalam pertanian organik, masa konversi atau masa transisi berlangsung selama 2-3 tahun sebelum panen pertama. Kesuburan tanah dan kegiatan biologi tanah harus dipertahankan dan ditingkatkan secara sepadan dengan penanaman legume, penambah bahan organik ke dalam tanah, baik dalam bentuk bahan yang telah dikomposkan maupun tidak. Hama, penyakit dan gulma dikendalikan dengan menggunakan kombinasi pemilihan jenis dan variasi yang tepat, pergiliran tanaman yang tepat, teknik pengendalian secara mekanik, pemeliharaan dan konservasi musuh alami dengan cara-cara yang menguntungkan seperti pelepasan predator, penyediaan tempat beristirahat, dll. (Sutanto, 2002; Sriyanto, 2010; Kunia, 2011).

Sampai saat ini belum pernah dilakukan pengembangan penelitian secara utuh yang 
berkaitan dengan diversitas populasi PBP di ekosistem sawah organik dan non organik. Dengan diminimalkannya penggunaan bahan kimia pada sawah organik, baik dalam bentuk pupuk maupun pestisida, tentunya memberi peluang meningkatnya diversitas populasi PBP, dibanding di sawah non organik yang masih menggunakan bahan kimia sintetis dalam bentuk pupuk maupun pestisida.

Diketahui terdapat 6 jenis penggerek batang padi di Jawa Tengah dengan potensi serangan yang bergantian, namun demikian data intensitas serangan PBP hanya menyebutkan serangan komplek PBP tanpa menyebutkan jenis yang mana sesungguhnya yang dominan/berpotensi. Selain itu juga apakah benar ke-enam jenis PBP tersebut ada di lapangan.

Sehubungan dengan hal itu maka dapat dirumuskan permasalahan : Bagaimana diversitas populasi PBP di ekosistem sawah organik dan anorganik. Jenis PBP yang mana yang paling dominan di ekosistem sawah organik dan anorganik atau memang mereka hidup di ekosistem sawah padi secara bersama-sama. Bagaimana fluktuasi diversitas populasi PBP selama 3 musim tanam padi di ekosistem sawah organik dan anorganik.

Penelitian ini bertujuan untuk mengkaji diversitas populasi PBP pada lahan sawah organik dan sawah anorganik di Desa Tegalrejo, Kecamatan Susukan, Kabupaten Semarang, Jawa Tengah, dengan mengukur diversitas (keragaman jenis dan kelimpahan) populasi PBP baik fase dewasa maupun fase telur di ekosistem sawah organik dan anorganik. Menentukan jenis PBP yang paling dominan di ekosistem sawah organik dan anorganik. Menentukan pola fluktuasi diversitas populasi PBP di ekosistem sawah organik dan anorganik selama 2-3 kali musim tanam padi.

\section{BAHAN DAN METODE}

Penentuan lokasi penelitan. Lokasi penelitian dipilih pada lahan sawah organik yang ditanami padi terus menerus sepanjang tahun, seluas 1 hektar bersertifikat nasional yang terletak di Desa Bakalrejo Kecamatan Susukan Kabupaten Semarang (Kelompok Tani : Green Grow). Sebagai pembanding dipilih lokasi pertanian anorganik yang bersebelahan dengan lokasi pertanian organik. Pada kedua lokasi penelitian tersebut, ditanami padi varietas IR-36, dengan waktu tanam bersamaan dengan penanaman padi di sekitarnya.

Metode kerja. Untuk mengetahui diversitas PBP di lokasi penelitian serta fluktuasinya dari waktu ke waktu, dilakukan pengambilan sampel kelompok telur maupun dewasa PBP pada tanaman padi fase vegetatip, generatip, pematangan dan bero, di ekosistem sawah organik dan anorganik. Pengamatan dan pengambilan sampel PBP, dilakukan setiap 2 minggu sekali selama 3 musim tanam padi (1 tahun) sejak pindah tanam. Pengambilan sampel PBP dewasa menggunakan perangkap lampu, perangkap malaise, jaring ayun dan plot kuadrat, yang dipasang secara diagonal di tengah-tengah area sawah. Sampel PBP dikoleksi dalam botol koleksi berisi alkohol 70\%. Pengambilan sampel kelompok telur PBP dilakukan dengan pengambilan langsung pada rumpun tanaman padi dalam plot ukuran 1 X 1 meter persegi di dalam area diagonal, di pagi hari setiap 2 minggu sekali selama 2-3 kali musim tanam padi (1 tahun). Kelompok telur PBP dikoleksi dalam tabung reaksi dan diberi label (Direktorat Perlindungan Tanaman Pangan Direktorat Jenderal Tanaman Pangan Departemen Pertanian, 2008; Prijono, Peggie \& Mulyadi. 2004).

\section{HASIL DAN PEMBAHASAN}

Penggerek batang padi (PBP) stadium telur yang dapat dijumpai di ekosistem sawah organik maupun sawah anorganik adalah $S$. incertulas (PBP Kuning) dan S. inferens (PBP merah jambu) (Tabel 1). Keberadaan telur PBP Kuning nampak pada setiap awal vegetatif tanaman padi baik pada ekosistem sawah organik maupun sawah anorganik, sedangkan telur PBP Merah jambu nampak hanya pada awal vegetatif tanaman padi di musim tanam pertama, dan pada musim tanam berikutnya tidak didapatkan lagi. Hal ini menunjukkan bahwa di ekosistem sawah baik sawah organik maupun anorganik PBP Kuning lebih dominan dibandingkan dengan PBP lainnya.

Persentase kehadiran $S$. incertulas dan $S$. inferens mempunyai kecenderungan yang hampir sama yaitu sedikit lebih banyak dijumpai pada 
ekosistem sawah organik dibandingkan pada ekosistem sawah anorganik (Gambar 1). Hal ini menunjukkan bahwa nampaknya penggerek batang padi lebih memilih ekosistem sawah organik di bandingkan dengan ekosistem sawah anorganik. $S$. incertulas, sebanyak $62 \%$ populasinya lebih memilih sawah organik sedangan 38\% lainnya memilih sawah anorganik. Begitupun dengan $S$. inferens, sebanyak $56 \%$ memilih sawah organik dan $44 \%$ lainnya memilih sawah anorganik.

Tabel 1. Penggerek batang padi stadium telur yang dikoleksi dengan metode plot di ekosistem sawah organik dan anorganik

\begin{tabular}{lcc}
\hline $\begin{array}{c}\text { Jenis perlakuan ekstrak } \\
(\mathrm{ppm})\end{array}$ & $\begin{array}{c}\text { Rerata kemunculan imago } \\
(\mathrm{x} \pm \mathrm{sd}) \text { ekor }\end{array}$ & $\begin{array}{c}\text { Rerata kemunculan imago } \\
(\mathrm{x} \pm \mathrm{sd}) \%\end{array}$ \\
\hline $85,99 \mathrm{ppm}\left(\mathrm{LC}_{25}\right)$ & $3,75 \pm 0,96 \mathrm{~b}$ & $45,00 \pm 0,55$ \\
$21,95 \mathrm{ppm}\left(\mathrm{LC}_{5}\right)$ & $2,00 \pm 0,00 \mathrm{a}$ & $22,22 \pm 0,00$ \\
Kontrol & $3,00 \pm 1,41 \mathrm{ab}$ & $38,15 \pm 0,49$ \\
\hline
\end{tabular}

Data yang diikuti dengan huruf yang sam dalam kolom yang sama menunjukkan data yang tidak berbeda nyata (Uji DMRT pada $\alpha=0,05)$

Hasil uji statistik menunjukkan bahwa kedua perlakuan ekstrak tersebut tidak berbeda nyata dengan kontrol. Hal ini berarti bahwa perlakuan ekstrak tidak berpengaruh terhadap kemunculan imago.

Lama perkembangan parasitoid stadium pradewasa ditentukan berdasarkan saat peletakan telur pertama kali sampai iumimago muncul dari pupa. Perlakuan ekstrak dengan konsentrasi 85,99 $\mathrm{mg} / \mathrm{L}$ ataupun $21,95 \mathrm{mg} / \mathrm{L}$ lama stadium pradewasa berdasarkan uji statistik berbeda nyata dengan kontrol. Pada kontrol, lama stadium pradewasa lebih lama dibanding dengan perlakuan ekstrak. Hal ini mungkin berkaitan dengan banyaknya nutrisi yang tersedia dalam tubuh inang. Lama hidup imago parasitoid jantan lebih pendek daripada parasitoid betina. Hal ini menunjukkan adanya adaptasi, dimana saat imago betina keluar dari pupa, imago jantan sudah matang secara seksual sehingga proses koplasi segera berlangsung (Tabel 2)

Tabel 2. Lama hidup Apantholeles sp. yang berkembang dari larva $S$. litura instar tiga yang telah diberi perlakuan ekstrak daun dan ranting $A$. odorata

\begin{tabular}{lccc}
\hline \multicolumn{1}{c}{ Jenis perlakuan ekstrak } & \multicolumn{3}{c}{ Lama hidup Apantheles sp. (x \pm sd) hari } \\
\multicolumn{1}{c}{$(\mathrm{ppm})$} & Pra dewasa & Dewasa jantan & Dewasa betina \\
\hline $85,99 \mathrm{ppm}\left(\mathrm{LC}_{25}\right)$ & $14,50 \pm 0,71 \mathrm{c}$ & $4,33 \pm 0,58 \mathrm{a}$ & $6,20 \pm 1,30 \mathrm{ab}$ \\
$21,95 \mathrm{ppm}\left(\mathrm{LC}_{5}\right)$ & $15,30 \pm 0,71 \mathrm{~b}$ & $4,60 \pm 0,55 \mathrm{a}$ & $6,90 \pm 0,74 \mathrm{a}$ \\
Kontrol & $17,30 \pm 0,71 \mathrm{a}$ & $5,00 \pm 1,00 \mathrm{a}$ & $5,43 \pm 0,76 \mathrm{~b}$ \\
\hline
\end{tabular}

Imago parasitoid betina yang baru muncul dari pupa biasanya langsung berkopulasi dan pada saat meletakkan telur, imago tersebut berputar mengelilingi inangnya sambil mengetuk-ngetukan antenanya pada tubuh inang. Segera setelah itu, ujung abdomennya disentuhkan pada tubuh inangnya untuk memasukkan ovipositornya. Banyaknya telur yang diletakkan dan yang terdapat di dalam ovarium parasitoid betina yang inangnya diperlakukan dengan ekstrak pada konsentrasi $85,99 \mathrm{mg} / \mathrm{L}$ berkisar antara 55-86 butir dengan rerata 69,40 butir/ betina, dan jumlah telur yang diletakkan 9,50 butir/hr. Perlakuan ekstrak pada kon sentrasi tersebut berdasarkan uji statistik tidak berbeda nyata dengan perlakuan $21,95 \mathrm{mg} / \mathrm{L}$ ataupun pada kontrol (Tabel 3) 
Tabel 3:Kepridian Apantheles sp yang berkembang dari larva S. litura instar tiga yang telah diberi perlakuan ekstrak daun dan ranting $A$. odorata

\begin{tabular}{llrrrr}
\hline No & Fase & \multicolumn{5}{c}{ Koleksi telur (metode plot) } \\
& Tanaman & S. incertulas & \multicolumn{2}{c}{ S. inferens } \\
\cline { 3 - 6 } & Padi & O & AO & O & AO \\
\hline 1 & Vegetatif & 15 & 24 & 0 & 2 \\
\hline 2 & Vegetatif & 5 & 10 & 81 & 35 \\
\hline 3 & Vegetatif & 4 & 9 & 0 & 0 \\
\hline 4 & Reproduktif & 9 & 1 & 0 & 0 \\
\hline 5 & Reproduktif & 0 & 0 & 0 & 0 \\
\hline 6 & Pemasakan & 0 & 0 & 0 & 0 \\
\hline 7 & Pemasakan & 0 & 0 & 0 & 0 \\
\hline 8 & Bero & 0 & 0 & 0 & 0 \\
\hline 9 & Bero & 0 & 0 & 0 & 0 \\
\hline 10 & Bero & 12 & 0 & 0 & 0 \\
\hline 11 & Vegetatif & 1 & 2 & 0 & 0 \\
\hline 12 & Vegetatif & 1 & 0 & 0 & 0 \\
\hline 13 & Vegetatif & 1 & 1 & 0 & 0 \\
\hline 14 & Reproduktif & 1 & 0 & 0 & 0 \\
\hline 15 & Reproduktif & 2 & 1 & 0 & 0 \\
\hline 16 & Pemasakan & 0 & 0 & 0 & 0 \\
\hline 17 & Pemasakan & 0 & 0 & 0 & 0 \\
\hline 18 & Bero & 0 & 0 & 0 & 0 \\
\hline 19 & Bero & 0 & 0 & 0 & 0 \\
\hline 20 & Bero & 0 & 0 & 0 & 0 \\
\hline 21 & Bero & 19 & 11 & 0 & 0 \\
\hline 22 & Vegetatif & 0 & 0 & 0 & 0 \\
\hline 23 & Vegetatif & 5 & 2 & 0 & 0 \\
\hline 24 & Vegetatif & 0 & 0 & 0 & 0 \\
\hline 25 & Reproduktif & 1 & 0 & 1 & 0 \\
\hline 26 & Reproduktif & 0 & 0 & 0 & 0 \\
\hline 27 & Pemasakan & 0 & 0 & 0 & 0 \\
\hline 28 & Pemasakan & 0 & 0 & 0 & 0 \\
\hline 29 & Bero & 0 & 0 & 0 & 0 \\
\hline & Jumlah & 76 & 60 & 82 & 37 \\
\hline & & & & & \\
\hline
\end{tabular}
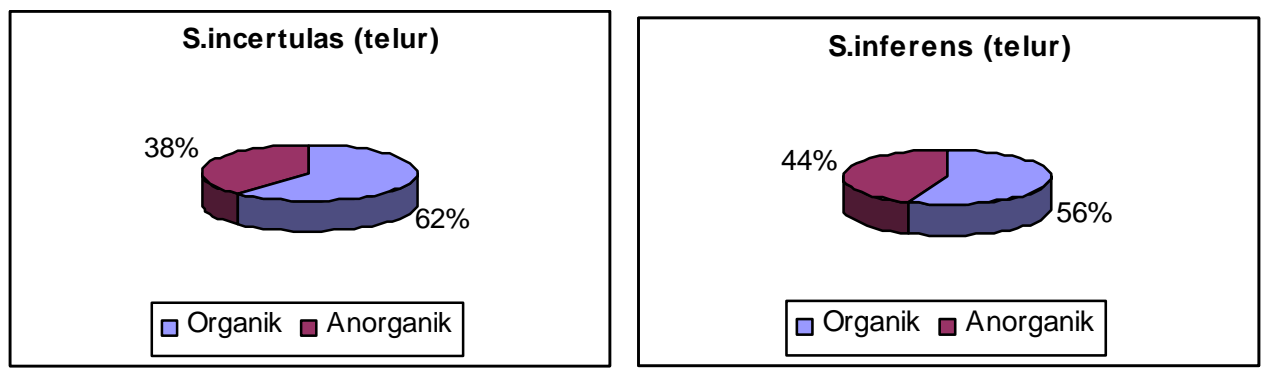

Gambar 1. Persentase penggerek batang padi S. incertulas dan S. inferens stadium telur yang dikoleksi dengan metode plot di ekosistem sawah organik dan anorganik. 
Penggerek batang padi dewasa yang berhasil dikoleksi dengan metode plot di ekosistem sawah organik maupun di sawah anorganik nampak pada Tabel 2. Dengan metode plot telah berhasil dikoleksi 4 jenis penggerek batang padi, yaitu PBP Kuning, PBP Putih, PBP Merah jambu dan PBP berkilat. Penggerek batang padi kuning $S$. incertulas nampak selalu ada pada setiap musim tanam padi, sedangkan penggerek batang padi lainnya S. innotata, S. inferens dan C. auricilius, hanya sesekali hadir di ekosistem sawah dan ada tidak pada setiap musim tanam padi. Dari Tabel 2 juga nampak bahwab $S$. inceretulas lebih dominan baik dari sisi frekuensi kehadiran maupun jumlah individunya. Hal ini menunjukkan bahwa penggerek batang padi kuning di ekosistem sawah memang lebih dominan dibandingkan dengan penggerek batang padi lainnya.

Secara persentase, S. incertulas, S. inferens maupun C. auricilius nampaknya lebih memilih ekosistem sawah organik dibandingkan dengan ekosistem sawah an organik (Gambar 2). Namun tidak demikian dengan $S$. innotata yang nampaknya lebih memilih ekosistem sawah anorganik dibandingkan dengan ekosistem sawah organik. Secara umum dapat dikatakan bahwa penggerek batang padi dewasa lebih memilih ekosistem sawah organik dibandingkan dengan ekosistem sawah anorganik.

Berdasarkan Gambar 2 nampak bahwa $62 \%$ populasi $S$. incertulas lebih memilih ekosistem sawah organik sedangkan $38 \%$ lainnya memilih sawah anorganik. Sedangkan S. inferens 56\% populasinya memilih ekosistem sawah organik sementara $44 \%$ lainnya memilih sawah anorganik. Populasi C. auricilius, $88 \%$ memilih ekosistem sawah organik dan $12 \%$ lainnya memilih sawah anorganik.

Tabel 2. Penggerek batang padi stadium dewasa yang dikoleksi dengan metode plot di ekosistem sawah organik dan sawah anorganik

\begin{tabular}{|c|c|c|c|c|c|c|}
\hline \multirow[t]{3}{*}{ No } & \multirow{3}{*}{$\begin{array}{c}\text { Fase } \\
\text { Tanaman } \\
\text { Padi }\end{array}$} & \multicolumn{5}{|c|}{$\begin{array}{l}\text { Koleksi Penggerek Batang Padi Dewasa (metode } \\
\text { Plot) }\end{array}$} \\
\hline & & $\begin{array}{c}S . \\
\text { incertulas }\end{array}$ & $\begin{array}{c}S . \\
\text { innotata }\end{array}$ & S. $i$ & ens & $\begin{array}{c}C . \\
\text { auricilius }\end{array}$ \\
\hline & & $\mathrm{O} \quad \mathrm{AO}$ & $\mathrm{O} \quad \mathrm{AO}$ & $\mathrm{O}$ & $\begin{array}{l}\mathrm{A} \\
\mathrm{O}\end{array}$ & $\mathrm{O} \quad \mathrm{AO}$ \\
\hline
\end{tabular}

\begin{tabular}{clllllllll}
1 & Vegetatif & 4 & 0 & 0 & 0 & 0 & 1 & 0 & 0 \\
\hline 2 & Vegetatif & 0 & 2 & 0 & 0 & 0 & 0 & 0 & 0 \\
\hline 3 & Vegetatif & 1 & 5 & 2 & 3 & 1 & 1 & 0 & 0 \\
\hline 4 & Reproduktif & 1 & 0 & 0 & 1 & 0 & 0 & 0 & 0 \\
\hline 5 & Reproduktif & 1 & 1 & 0 & 0 & 0 & 0 & 1 & 0 \\
\hline 6 & Pemasakan & 1 & 1 & 0 & 0 & 0 & 0 & 0 & 1 \\
\hline 7 & Pemasakan & 0 & 0 & 0 & 0 & 0 & 0 & 0 & 0 \\
\hline 8 & Bero & 0 & 0 & 0 & 0 & 0 & 0 & 0 & 0 \\
\hline 9 & Bero & 13 & 0 & 0 & 0 & 0 & 0 & 0 & 0 \\
\hline 10 & Bero & 0 & 0 & 0 & 3 & 0 & 0 & 3 & 2 \\
\hline 11 & Vegetatif & 1 & 1 & 0 & 0 & 0 & 0 & 0 & 0 \\
\hline 12 & Vegetatif & 6 & 6 & 0 & 0 & 0 & 0 & 0 & 0 \\
\hline 13 & Vegetatif & 0 & 0 & 0 & 0 & 0 & 0 & 0 & 0 \\
\hline 14 & Reproduktif & 0 & 0 & 0 & 0 & 0 & 0 & 0 & 0 \\
\hline 15 & Reproduktif & 0 & 1 & 1 & 1 & 0 & 0 & 0 & 0 \\
\hline 16 & Pemasakan & 0 & 2 & 0 & 0 & 0 & 0 & 0 & 0 \\
\hline 17 & Pemasakan & 0 & 0 & 0 & 0 & 0 & 0 & 0 & 0 \\
\hline 18 & Bero & 0 & 0 & 0 & 0 & 0 & 0 & 0 & 0
\end{tabular}




\begin{tabular}{llllllllll}
19 & Bero & 0 & 0 & 0 & 0 & 0 & 0 & 0 & 0 \\
\hline 20 & Bero & 7 & 3 & 0 & 0 & 0 & 0 & 0 & 0 \\
\hline 21 & Bero & 0 & 1 & 0 & 0 & 0 & 0 & 0 & 0 \\
\hline 22 & Vegetatif & 4 & 2 & 0 & 0 & 0 & 0 & 0 & 0 \\
\hline 23 & Vegetatif & 2 & 5 & 0 & 0 & 2 & 0 & 0 & 0 \\
\hline 24 & Vegetatif & 0 & 0 & 0 & 0 & 2 & 0 & 0 & 0 \\
\hline 25 & Reproduktif & 0 & 0 & 0 & 0 & 0 & 0 & 0 & 0 \\
\hline 26 & Reproduktif & 0 & 0 & 0 & 0 & 0 & 0 & 0 & 0 \\
\hline 27 & Pemasakan & 0 & 0 & 0 & 0 & 0 & 0 & 0 & 0 \\
\hline 28 & Pemasakan & 0 & 0 & 0 & 0 & 0 & 0 & 0 & 0 \\
\hline 29 & Bero & 0 & 0 & 0 & 0 & 0 & 0 & 0 & 0 \\
\hline & & & & & & & & & \\
& Jumlah & 41 & 30 & 3 & 8 & 5 & 2 & 4 & 3 \\
\hline
\end{tabular}
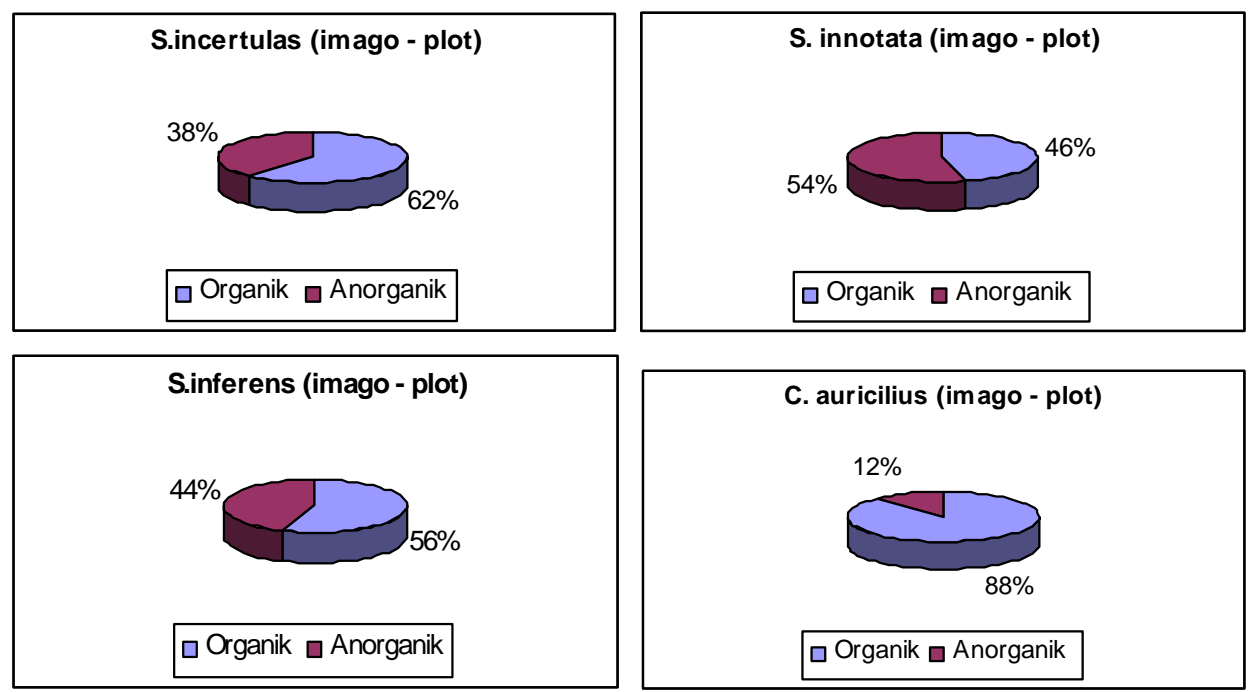

Gambar 2. Persentase penggerek batang padi S. incertulas, S. innotata, S. inferens dan C. auricilius dewasa yang dikoleksi dengan metode plot di ekosistem sawah organik dan sawah anorganik

Tabel 3. Penggerek batang padi stadium dewasa yang dikoleksi dengan metode jaring ayun di ekosistem sawah organik dan sawah anorganik

\begin{tabular}{|c|c|c|c|c|c|}
\hline \multirow[t]{3}{*}{ No } & \multirow[t]{3}{*}{$\begin{array}{c}\text { Fase } \\
\text { Tanaman Padi }\end{array}$} & \multicolumn{4}{|c|}{$\begin{array}{l}\text { Koleksi Penggerek Batang Padi } \\
\text { Dewasa (Metode Jaring Ayun) }\end{array}$} \\
\hline & & \multicolumn{2}{|c|}{ S. incertulas } & \multicolumn{2}{|c|}{ S. innotata } \\
\hline & & $\mathrm{O}$ & $\mathrm{AO}$ & $\mathrm{O}$ & $\mathrm{AO}$ \\
\hline 1 & Vegetatif & 5 & 0 & 0 & 0 \\
\hline 2 & Vegetatif & 8 & 1 & 0 & 0 \\
\hline 3 & Vegetatif & 7 & 1 & 3 & 0 \\
\hline 4 & Reproduktif & 1 & 0 & 0 & 0 \\
\hline 5 & Reproduktif & 2 & 1 & 0 & 0 \\
\hline 6 & Pemasakan & 0 & 3 & 0 & 0 \\
\hline 7 & Pemasakan & 0 & 0 & 0 & 0 \\
\hline 8 & Bero & 0 & 0 & 0 & 0 \\
\hline 9 & Bero & 0 & 2 & 0 & 0 \\
\hline
\end{tabular}




\begin{tabular}{llclll}
\hline 10 & Bero & 0 & 0 & 0 & 0 \\
\hline 11 & Vegetatif & 3 & 0 & 0 & 0 \\
\hline 12 & Vegetatif & 1 & 7 & 0 & 0 \\
\hline 13 & Vegetatif & 21 & 5 & 0 & 0 \\
\hline 14 & Reproduktif & 4 & 5 & 0 & 0 \\
\hline 15 & Reproduktif & 0 & 8 & 0 & 0 \\
\hline 16 & Pemasakan & 5 & 7 & 0 & 0 \\
\hline 17 & Pemasakan & 1 & 6 & 0 & 0 \\
\hline 18 & Bero & 0 & 0 & 0 & 0 \\
\hline 19 & Bero & 2 & 1 & 0 & 0 \\
\hline 20 & Bero & 4 & 3 & 0 & 0 \\
\hline 21 & Bero & 2 & 0 & 0 & 0 \\
\hline 22 & Vegetatif & 3 & 2 & 0 & 0 \\
\hline 23 & Vegetatif & 4 & 0 & 0 & 0 \\
\hline 24 & Vegetatif & 2 & 4 & 0 & 0 \\
\hline 25 & Reproduktif & 0 & 0 & 0 & 0 \\
\hline 26 & Reproduktif & 0 & 0 & 0 & 0 \\
\hline 27 & Pemasakan & 0 & 0 & 0 & 0 \\
\hline 28 & Pemasakan & 1 & 0 & 0 & 0 \\
\hline 29 & Bero & 0 & 0 & 0 & 0 \\
\hline & Jumlah & 76 & 56 & 3 & 0 \\
\hline & & & & &
\end{tabular}

Penggerek batang padi dewasa yang berhasil dikoleksi dengan jaring ayun, adalah $S$. incertulas dan $S$. innotata (Tabel 3). Nampak bahwa $S$. incertulas ada pada setiap musim tanam padi baik pada ekosistem sawah organik maupun sawah anorganik. Sedangkan S. innotata hanya hadir sekali saja pada ekosistem sawah organik dan tidak pada sawah anorganik. Hal ini membuktikan bahwa penggerek batang padi kuning $S$. incertulas di ekosistem sawah baik organik maupun

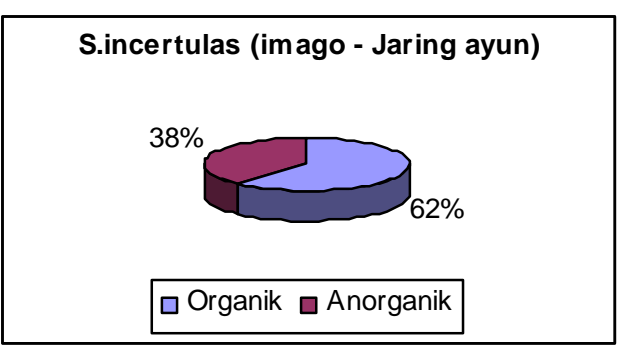

anorganik lebih dominan dibandingkan dengan penggerek batang padi lainnya. Ternyata bahwa $62 \%$ populasinya lebih memilih ekosistem sawah organik dibandingkan dengan ekosistem sawah anorganik (38\%). Sebaliknya S. innotata $100 \%$ populasinya memilih ekosistem sawah organik (Gambar 3).

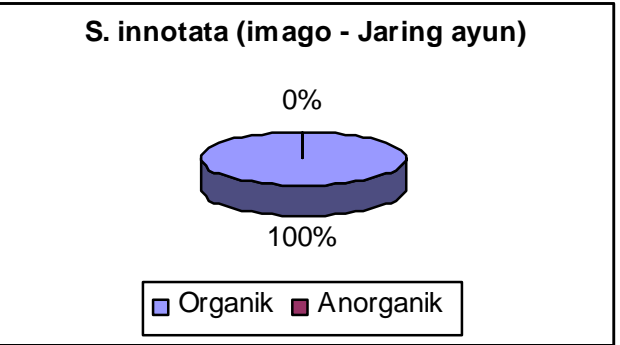

Gambar 3. Persentase penggerek batang padi S. incertulas dan S. innotata dewasa yang dikoleksi dengan metode jaring ayun di ekosistem sawah organik dan sawah anorganik 
Tabel 4. Penggerek batang padi stadium dewasa yang dikoleksi dengan metode Malaise di ekosistem sawah organik dan sawah anorganik

\begin{tabular}{llll}
\hline No & Fase Tanaman Padi & \multicolumn{2}{c}{ Koleksi PBP } \\
& & Sewasa (Malaise) \\
\cline { 2 - 4 } & & O incertulas \\
\cline { 3 - 4 } & & 0 & AO \\
\hline & Vegetatif & 0 & 0 \\
\hline 2 & Vegetatif & 0 & 0 \\
\hline 3 & Vegetatif & 0 & 0 \\
\hline 4 & Reproduktif & 0 & 0 \\
\hline 5 & Reproduktif & 1 & 0 \\
\hline 6 & Pemasakan & 0 & 0 \\
\hline 7 & Pemasakan & 0 & 0 \\
\hline 8 & Bero & 0 & 0 \\
\hline 9 & Bero & 0 & 0 \\
\hline 10 & Bero & 4 & 0 \\
\hline 11 & Vegetatif & 1 & 0 \\
\hline 12 & Vegetatif & 0 & 0 \\
\hline 13 & Vegetatif & 0 & 0 \\
\hline 14 & Reproduktif & 0 & 0 \\
\hline 15 & Reproduktif & 0 & 1 \\
\hline 16 & Pemasakan & 0 & 0 \\
\hline 17 & Pemasakan & 0 & 0 \\
\hline 18 & Bero & 0 & 0 \\
\hline 19 & Bero & 3 & 0 \\
\hline 20 & Bero & 0 & 1 \\
\hline 21 & Bero & 0 & 0 \\
\hline 22 & Vegetatif & 0 & 0 \\
\hline 23 & Vegetatif & 0 & 0 \\
\hline 24 & Vegetatif & 0 \\
\hline 25 & Reproduktif & 0 \\
\hline 26 & Reproduktif & 0 \\
\hline 27 & Pemasakan & 0 \\
\hline 28 & Pemasakan & 0 \\
\hline 29 & Bero & 0 \\
\hline & & 0 & 0 \\
\hline & Jumlah & 0 & 0 \\
\hline
\end{tabular}


Dengan metode malaise, hanya diperoleh penggerek batang padi kuning saja, walaupun tidak dalam jumlah besar (Tabel 4). Secara persentase, penggerek batang padi kuning ini, $83 \%$ populasinya dijumpai di ekosistem sawah organik, sedangkan $17 \%$ lainnya dijumpai di ekosistem sawah anorganik (Gambar 4).

\section{S.incertulas (imago - Malaise)}

\section{$17 \%$}

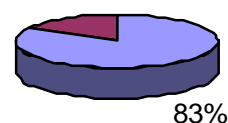

$\square$ Organik $\square$ Anorganik

Gambar 4. Persentase penggerek batang padi $S$. incertulas dewasa yang dikoleksi dengan metode malaise di ekosistem sawah organik dan sawah anorganik

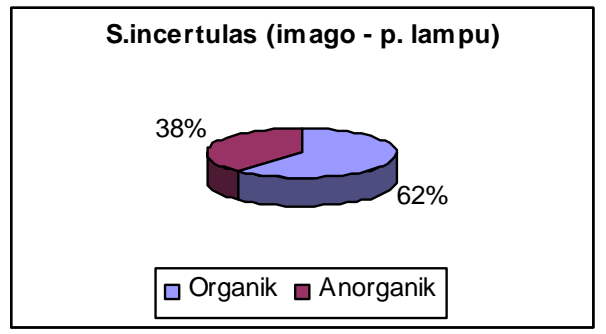

C. auricilius (imago - p. lampu)

$12 \%$

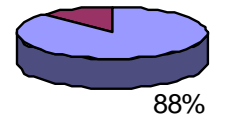

口 Organik $\square$ Anorganik
Dengan perangkap lampu dapat dikoleksi 4 jenis penggerek batang, yaitu PBP kuning, PBP putih, PBP merah jambu dan PBP berkilat (Tabel 5), nampak bahwa PBP kuning dapat dijumpai di setiap waktu sepanjang tahun di setiap fase pertumbuhan tanaman padi. Di sawah organik sepanjang tahun dapat dikoleksi 453 individu PBP kuning, sedangkan di sawah anorganik 283 individu PBP kuning. PBP merah jambu sepanjang tahun dapat dikoleksi 18 individu di sawah organik dan 21 individu di sawah anorganik. Sementara itu PBP putih dan PBP berkilat hanya dijumpai pada waktu awal musim tanam padi yang pertama dan selanjutnya pada musim tanam padi berikutnya tidak dijumpai lagi.

Gambar 5. Persentase penggerek batang padi S. incertulas, S. innotata, S.inferens dan C. Incertulas dewasa yang dikoleksi dengan metode perangkap lampu di ekosistem sawah organik dan sawah anorganik. 
Tabel 5. Penggerek batang padi stadium dewasa yang dikoleksi dengan metode perangkap lampu di ekosistem sawah organik dan sawah anorganik

\begin{tabular}{|c|c|c|c|c|c|c|c|c|c|}
\hline \multirow[t]{3}{*}{ No } & \multirow{3}{*}{$\begin{array}{l}\text { Fase } \\
\text { Tanaman } \\
\text { Padi }\end{array}$} & \multicolumn{8}{|c|}{ Koleksi PBP dewasa (Perangkap Lampu) } \\
\hline & & \multicolumn{2}{|c|}{ S. incertulas } & \multicolumn{2}{|c|}{ S. innotata } & \multicolumn{2}{|c|}{$\begin{array}{l}S . \\
\text { inferens }\end{array}$} & \multicolumn{2}{|c|}{$\begin{array}{l}C . \\
\text { auricilius }\end{array}$} \\
\hline & & $\mathrm{O}$ & $\mathrm{AO}$ & $\mathrm{O}$ & $\mathrm{AO}$ & $\mathrm{O}$ & $\mathrm{AO}$ & $\mathrm{O}$ & $\mathrm{AO}$ \\
\hline 1 & Vegetatif & 7 & 2 & 0 & 0 & 0 & 0 & 7 & 0 \\
\hline 2 & Vegetatif & 20 & 10 & 11 & 12 & 2 & 5 & 14 & 3 \\
\hline 3 & Vegetatif & 17 & 15 & 7 & 9 & 1 & 2 & 1 & 0 \\
\hline 4 & Reproduktif & 26 & 10 & 0 & 0 & 2 & 0 & 0 & 0 \\
\hline 5 & Reproduktif & 1 & 0 & 0 & 0 & 2 & 0 & 0 & 0 \\
\hline 6 & Pemanakan & 13 & 15 & 0 & 0 & 0 & 0 & 0 & 0 \\
\hline 7 & Pemasakan & 9 & 4 & 0 & 0 & 0 & 0 & 0 & 0 \\
\hline 8 & Bero & 20 & 4 & 0 & 0 & 1 & 0 & 0 & 0 \\
\hline 9 & Bero & 11 & 11 & 0 & 0 & 1 & 0 & 0 & 0 \\
\hline 10 & Bero & 3 & 1 & 0 & 0 & 0 & 0 & 0 & 0 \\
\hline 11 & Vegetatif & 18 & 5 & 0 & 0 & 0 & 0 & 0 & 0 \\
\hline 12 & Vegetatif & 51 & 13 & 0 & 0 & 1 & 3 & 0 & 0 \\
\hline 13 & Vegetatif & 47 & 15 & 0 & 0 & 2 & 0 & 0 & 0 \\
\hline 14 & Reproduktif & 29 & 21 & 0 & 0 & 0 & 0 & 0 & 0 \\
\hline 15 & Reproduktif & 26 & 18 & 0 & 0 & 4 & 7 & 0 & 0 \\
\hline 16 & Pemasakan & 13 & 12 & 0 & 0 & 4 & 3 & 0 & 0 \\
\hline 17 & Pemasakan & 17 & 15 & 0 & 0 & 5 & 5 & 0 & 0 \\
\hline 18 & Bero & 6 & 7 & 0 & 0 & 0 & 0 & 0 & 0 \\
\hline 19 & Bero & 11 & 10 & 0 & 0 & 0 & 0 & 0 & 0 \\
\hline 20 & Bero & 0 & 0 & 0 & 0 & 0 & 0 & 0 & 0 \\
\hline 21 & Bero & 25 & 17 & 0 & 0 & 0 & 0 & 0 & 0 \\
\hline 22 & Vegetatif & 4 & 4 & 0 & 0 & 0 & 0 & 0 & 0 \\
\hline 23 & Vegetatif & 22 & 27 & 0 & 0 & 0 & 0 & 0 & 0 \\
\hline 24 & Vegetatif & 9 & 4 & 0 & 0 & 4 & 0 & 0 & 0 \\
\hline 25 & Reproduktif & 23 & 18 & 0 & 0 & 2 & 0 & 0 & 0 \\
\hline 26 & Reproduktif & 5 & 2 & 0 & 0 & 0 & 0 & 0 & 0 \\
\hline 27 & Pemasakan & 15 & 9 & 0 & 0 & 0 & 0 & 0 & 0 \\
\hline 28 & Pemasakan & 0 & 5 & 0 & 0 & 1 & 0 & 0 & 0 \\
\hline 29 & Bero & 5 & 9 & 0 & 0 & 1 & 1 & 0 & 0 \\
\hline & Jumlah & 453 & 283 & 18 & 21 & 33 & 26 & 22 & 3 \\
\hline
\end{tabular}

Persentase kehadiran populasi PBP di ekosistem sawah organik dan sawah anorganik (Gambar 5). Nampak bahwa PBP kuning, PBP merah jambu dan PBP berkilat lebih memilih ekosistem sawah organik dibandingkan sawah anorganik. PBP kuning, $62 \%$ populasinya dijumpai di sawah organik dan $38 \%$ lainnya di sawah anorganik. PBP merah jambu, 56\% populasinya dijumpai dai sawah organik dan $44 \%$ lainnya dijumpai di sawah anorganik. PBP berkilat, $88 \%$ populasinya dijumpai di sawah organik sedangkan $12 \%$ lainnya dijumpai di sawah anorganik. Sementara itu, PBP putih 46\% populasinya dijumpai di ekosistem sawah organik dan 54\% dujumpai di sawah anorganik. Dengan demikian dapat dikatakan bahwa secara umum di ekosistem sawah dapat dijumpai 4 jenis penggerek batang padi, tetapi hanya PBP kuning yang dapat dijumpai sepanjang waktu. Jenis PBP yang lain dijumpai hanya kadang-kadang saja. 


\section{KESIMPULAN}

Di ekosistem sawah organik maupun sawah anorganik, PBP yang dapat dijumpai adalah 4 jenis (S. incertulas, $S$. inferens, $S$. innotata dan $C$. auricilius), namun demikian hanya PBP kuning $S$. incertulas saja yang dominan yang dapat dijumpai sepanjang tahun. PBP cenderung lebih memilih ekosistem sawah organik dibandingkan sawah anorganik, walaupun fluktuasinya sepanjang tahun memiliki pola yang cenderung sama.

\section{UCAPAN TERIMA KASIH}

Ucapan terima kasih disampaikan kepada saudara Widodo, Surya Imdad Nurcahya, Rizqi Hadi Pratama, Aminah, Shinta Aryani, dan Roma Witriyanto, yang telah membantu dalam pengambilan data di lapangan. Ucapan terima kasih juga disampaikan kepada ibu Siti Sunarti dan bapak Suwardjo serta bapak Fathurohman atas ijin yang diberikan menggunakan sawah miliknya sebagai lokasi penelitian.

\section{DAFTAR PUSTAKA}

Balai Besar Penelitian Tanaman Padi, 2009. Penggerek batang padi. http://bbpadi.litbang.deptan.go.id.

Direktorat Perlindungan Tanaman Pangan Direktorat Jenderal Tanaman Pangan Departemen Pertanian. 2008. Pedoman Pengamatan Dan Pelaporan Perlindungan Tanaman Pangan. Departemen Pertanian. Jakarta.

Hattori and Siwi, 1986. Rice Stem Borers in Indonesia. Dalam Direktorat Jendral Pertanian Tanaman Pangan, Direktorat Bina Perlindungan Tanaman (2007) Pedoman Teknis Pengendalian Hama dan Penggerek Batang Padi. Departemen Pertanian, Jakarta.

IFOAM, 2005. Principles of Organic Abriculture. International Federation of Organic Agriculture Movements (IFOAM). Germany

Kalshoven, LGE, 1981. The pest of crops in Indonesia. PT Ichtiar Baru, Jakarta

Kunia, K, 2011. Pertanian Organik, teknologi ramah lingkungan.
Mutiarawati, T, 2006. Kendala dan Peluang Dalam Produksi Pertanian Organik di Indonesia. Makalah Ilmiah Fakultas Pertanian Universitas Padjadjaran Bandung

Prijono, SN, D Peggie \& Mulyadi. 2004. Pedoman Pengumpulan Data Keanekaragaman Fauna. Puslit Biologi LIPI Bogor

Siwi, SS. 1979. Identifikasi Penggerek Batang Padi Di Indonesia. Konggres Entomologi I. Jakarta

Soehardjan, M. 1983. Dinamika Populasi Penggerek Kuning Padi Tryporiza incertulas (Walker) (Pyralidae, Lepidoptera). Disertasi Institut Teknologi Bandung.

Soejitno, J. 1986. Pengaruh Serangan Penggerek Padi Kuning Tryporiza incertulas (Walker) Pada Berbagai Umur Tanaman Terhadap Kerusakan Tanaman Padi. Lembaga Penelitian Pertanan. Bogor.

Sriyanto,S, 2010. Panen Duit dari Bisnis Padi Organik. AgroMedia Pustaka. Jakarta.

Subiyakto. 1982. Dominansi Jenis Penggerek Batang Padi Pada Tanaman Padi Var IR-34. Tesis Fakultas Biologi UGM.

Suharto. 2007. Pengenalan dan Pengendalian Hama Tanaman Pangan. Andi Offset. Yogyakarta.

Suharto, H \& N Usyati, 2005. The Stem borer infestation on rice cultivars at three planting times. Indonesian Journal of agricultural science.

Sutanto, R, 2002. Pertanian Organik, menuju pertanian alternatif dan berkelanjutan. Kanisius Yogyakarta.

Sutarna, 1999. Perkembangan Populasi Penggerek Batang Padi Scirpophaga incertulas (Walker) Pada Tanaman Padi Oryza sativa L. Var IR-64 Pada Pertanaman Musim Hujan di Banguntapan Bantul. Tesis Fakultas Biologi UGM.

Urip S, 2009. Pengembangan model peramalan hama penggerek batang padi kuning. http://saungurip.blogspot.com. http://kunia.wordpress.com. 
BIOMA, Desember 2015

Vol. 17, No. 2, Hal. 106-117

ISSN: 1410-8801 